BYU Studies Quarterly

Volume 53 | Issue 3

Article 5

9-1-2014

\title{
"The Spiritual Concept of Form and Function as One": Structure, Doctrine, and The Church of Jesus Christ of Latter-day Saints
}

Cheryl B. Preston

Follow this and additional works at: https://scholarsarchive.byu.edu/byusq

\section{Recommended Citation}

Preston, Cheryl B. (2014) "'The Spiritual Concept of Form and Function as One": Structure, Doctrine, and The Church of Jesus Christ of Latter-day Saints," BYU Studies Quarterly: Vol. 53 : Iss. 3 , Article 5.

Available at: https://scholarsarchive.byu.edu/byusq/vol53/iss3/5 


\title{
"The Spiritual Concept of Form and Function as One"
}

Structure, Doctrine, and The Church of Jesus Christ of Latter-day Saints

\author{
Cheryl B. Preston
}

\begin{abstract}
A New Yorker lured to Scottsdale, Arizona, with the promise of an architectural wonderland will likely be disappointed. Unlike the dramatic skyline of New York, Paris, or Rome, the homes and buildings of Scottsdale are relatively flat, squat, and unadorned. Driving through northeast Scottsdale, only the astute will spot the treasure there. The buildings rise almost imperceptibly within their surroundings. They do not jut dramatically skyward to demonstrate the creative power of their designer. They do not flaunt the owner's wealth with pillars, gilding, or ornamentation. Rather, the unpretentious structures quietly perform the function for which they were designed. In their designer's own words: "Conceive now that an entire building might grow up out of [natural] conditions as a plant grows up out of soil and yet be free to be itself, ... [d]ignified as a tree in the midst of nature but a child of the spirit of man." The buildings that house the Frank Lloyd Wright Institute of Architecture, collectively called Taliesin West, have managed to survive magnificently the vagaries of fashion and style trends-survive quietly, almost spiritually.

In this article, I will illustrate how the structure (form) of The Church of Jesus Christ of Latter-day Saints interacts with theological substance and doctrine (function) to create an entity in harmony with the ideals
\end{abstract}

1. Frank Lloyd Wright, Frank Lloyd Wright: An Autobiography (1943; Petaluma, Calif.: Pomegranate Communications, 2005), 146.

2. Wright, Autobiography, 147. 


\section{Cheryl B. Preston}

This article evolved from thinking about how to translate the language of religious studies into the world of The Church of Jesus Christ of Latter-day Saints. As I analyzed concepts behind such common terms as "canon" and "lawgivers," I was surprised to discover that Church structure is, in many ways, less hierarchical than might be expected by an outsider. The LDS Church offers unique opportunities for integrating the individual memberworshipper in theological knowledge

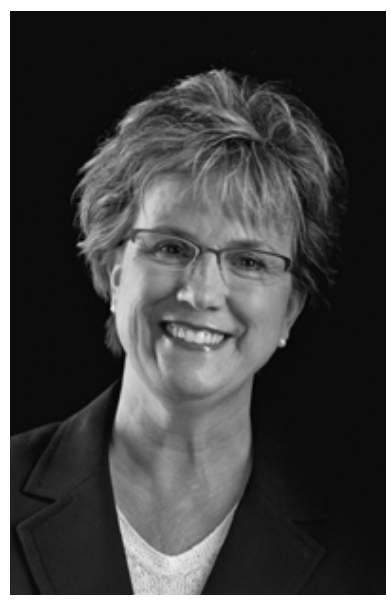
and practice. The intersection of horizontal and vertical forms in the Church functions to enhance the experiences that carry substantive significance in LDS theology. Seeing this intersection of form and function, reminiscent of the architecture of Frank Lloyd Wright, was for me spiritually affirming.

expressed by Frank Lloyd Wright's theory of architecture. As Wright said, "Form and function thus become one ... if the nature of materials and method and purpose are all in unison." ${ }^{3}$ The Church achieves such spiritual unity because the materials that constitute the vertical and horizontal administrative structures (form) of the Church are in harmony with the substance and purpose (function) for which the Church exists. In the Church, the "spiritual and material are naturally of each other."

When I first undertook this exploration of the form of the Church, it was for the purpose of responding to a request from the editors of an international publication on comparative religions. I was asked to describe the Church in relation to several fixed questions: What is the

3. Wright, Autobiography, 338.

4. Frank Lloyd Wright, Genius and the Mobocracy (New York: Duell, Sloan and Pearce, 1949), 83. 
canon? Who are the lawmakers? Who forms the theology? Specifically, who are the official interpreters, what comprises the body of theological works, and what are the methods of interpretation? These are quite intriguing questions in the Latter-day Saint context since we do not customarily speak of "canon," "lawmakers," or "theology" with the meanings these words have in many world religions. I published my chapter, ${ }^{5}$ but my interest in the topic did not wane. In the process of transcribing the concepts of canon, lawmakers, and theology from Church contexts, I was awed by the realization of the extent to which the organization of the Church fosters particular spiritual objectives.

This article consists of two parts. Part 1 considers the question of Latter-day Saint structure from an academic perspective, along the line of a comparative religion study. It is not derived from the discipline of structuralist analysis, but rather from the perspective of legal systems. It considers the Church as a formal, but not always expressly articulated, institution system. Part 2 is a personal and religious discussion of how the structure described in part 1 interacts with and enhances doctrine and spiritual concepts. This change of focus may mean the two parts will appeal to different audiences or to the same audience on different levels.

While it may seem unnecessary to describe Church structure to a largely Latter-day Saint audience, part 1 provides a framework for thinking about the Church's organization in comparison to other churches and institutions. Part 1A describes the two elements of the vertical structure of the Church-leaders and canon-and the importance of the lack of a third pillar in the form of official theological interpreters. Part 1в turns to horizontal structural forms, noting that in many respects these are dissimilar to the structure of other churches. Horizontally, the Church is formed by the use of lay leaders, councils, and the communitarian and experiential learning processes.

Part 2 considers how the structure of the Church, both vertical and horizontal, facilitates the learning and application of certain doctrinal tenets. Part 2A discusses individual ownership of the religious experience. Part 2B considers the significance of experience in the Church's theology. Part 2C addresses the related concept of individual light and

5. Cheryl B. Preston, "The Canon, Lawmakers and the Right to Interpret in The Church of Jesus Christ of Latter-day Saints," Daimon: Annuario di Diritto Comparato Delle Religioni 6 (December 2006): 115-6o. 
knowledge. The whole of Part 2 concludes with the design of a modern temple as an illustration of the integration and unification of the Church's form and function.

One important substantive aspect of Latter-day Saint doctrine greatly impacts the structure of the Church and so merits mentioning upfront: the kingdom of God in a fallen world operates through imperfect mortals. As a result, some elements of structure and form may become unnecessary, along with the personnel who compose them. On the other hand, these elements may be reconceived as we accept more light ${ }^{6}$ and move toward a perfect system in the Millennium and throughout eternity. I am not arguing that every detail of the current form of the Church is perfect or that none of the individual components will ever be changed. I only argue that the design of these forms facilitates the development of core spiritual principles currently needed by members of the Church.

\section{Part 1: Structure of the Church}

\section{A. Latter-day Saint Vertical Form}

Part 1 articulates the vertical structure of the Church in the terms of comparative religious study. While the Church has lawmakers and canon like other Western Christian denominations, the details in how these play out are in many ways dissimilar. Moreover, the Church does not have what most academics would consider a systematic theologyofficial scholarly interpretation of the canon.

1. Latter-day Saint Lawmakers. Latter-day Saints are unlikely to speak in terms of "lawmakers," other than with respect to Jesus Christ. But law exists and is made at several levels of the Church, and the individuals invested with this function are set apart and publicly sustained. This part delineates Latter-day Saint lawmakers from those with the broadest jurisdiction to those with the narrowest-from grand eternal law to the decisions that organize a person's individual relationship to the Church.

6. See Isaiah 28:10 ("For precept must be upon precept, precept upon precept; line upon line, line upon line; here a little, and there a little"); Luke 8:18 ("Take heed therefore how ye hear: for whosoever hath, to him shall be given; and whosoever hath not, from him shall be taken even that which he seemeth to have"). 
The highest source of authority in Latter-day Saint doctrine is God, who governs the universe by "law, irrevocably decreed in heaven before the foundations of this world" (D\&C 130:20). The principles of this firstlevel eternal law and its makers ${ }^{7}$ are little understood in human terms, although Latter-day Saints believe these laws to mandate choice and accountability, as well as justice and mercy. ${ }^{8}$ Within the governance of

7. Brigham Young, in Journal of Discourses, 26 vols. (Liverpool: F. D. Richards, 1855-86), 13:140-41 (teaching that God works within natural physical laws). See also James E. Talmage, The Articles of Faith: A Series of Lectures on the Principal Doctrines of The Church of Jesus Christ of Latter-day Saints (Salt Lake City: Deseret News, 1919), 220-23 (explaining miracles as the operation of natural law). See generally David H. Bailey, "Mormons and the Omnis: The Dangers of Theological Speculation," Dialogue 37, no. 3 (2004): 29, available at http://www.dhbailey.com/papers/dhb-omnis.pdf (explaining the LDS view of Deity as bound by the same laws set forth to bind his mortal children). The exact relationship between God and pre-earth life law remains unclear. James E. Faulconer, professor of philosophy at Brigham Young University, comments on this dispute: "At least beginning in 1855 and continuing for ten years or more, Orson Pratt and Brigham Young had a running battle over the nature of the Godhead. ... Pratt argued in a variety of ways that to be a God was to partake of an already existing divine perfection and that to worship those perfections was to worship God. . . . In one of several condemnations of Pratt's teachings, Brigham Young said, 'It was neither rational nor consistent with the revelations of God and with reason and philosophy, to believe that these latter Forces and Powers had existed prior to the Beings who controlled and governed them." Brigham Young, Heber C. Kimball, and Daniel H. Wells, "Hearken, O Ye Latter-day Saints, August 23, 1865," in Messages of the First Presidency of The Church of Jesus Christ of Latter-day Saints, 1833-1964, comp. James R. Clark, 6 vols. (Salt Lake City: Bookcraft, 1965-75), 2:232. "It seems to me," Faulconer continues, "that if there were not forces and powers prior to the Gods who control them, then there were not laws pre-existing God that he must obey. The primary philosophical argument against there being laws that God must obey can be reduced to a rhetorical question: 'If God must obey Law, then why isn't Law God?' In other words, if there is something perfect that preexists God, isn't Pratt right that we should worship it? Of course the idea that God does obey eternal laws has [nonetheless] gained currency in the Church." James E. Faulconer to author, email, January 28, 2006.

8. See Gene R. Cook, Receiving Answers to Our Prayers (Salt Lake City: Deseret Book, 1996), 120-27 (explaining the LDS concept of grace as God's power contributed after one has given her best efforts). 
this eternal law, Jesus Christ is the "one lawgiver" for this world (James $4: 12),{ }^{9}$ acting for the entire Godhead because they are one in purpose. ${ }^{10}$

As Christ's representatives on earth, the First Presidency and the Quorum of the Twelve Apostles ${ }^{11}$ are known as "prophets, seers, and revelators", ${ }^{2}$ and each is sometimes referenced in shorthand as a "prophet." The prophets in this collective sense form the primary avenue through which Christ reveals his law to his people, and Latter-day Saints are to receive their official words as if they were the words of the Lord. ${ }^{13}$ Scripture is replete with warnings to those who would reject the prophets. ${ }^{14}$ As discussed below in part $1 \mathrm{~B}$, the belief that the Lord continues to communicate to the world through his prophets is a foundational tenet of the Latter-day Saint faith (see A of F 9). Prophets, seers, and revelators are the only lawgivers for the entire Church, and they are the only lawgivers who are authorized to establish doctrine. ${ }^{15}$ They also promulgate

9. See also, for example, 3 Nephi 15:9 ("Behold, I am the law, and the light. Look unto me, and endure to the end, and ye shall live; for unto him that endureth to the end will I give eternal life"); Doctrine and Covenants 88:13 ("JJesus Christ is] the light which is in all things, which giveth life to all things, which is the law by which all things are governed, even the power of God who sitteth upon his throne, who is in the bosom of eternity, who is in the midst of all things"). Latter-day Saints also believe that Christ's role as lawgiver will continue after his Second Coming, while he reigns personally on the earth. See Doctrine and Covenants 45:59 ("For the Lord shall [then] be in their midst, and his glory shall be upon them, and he will be their king and their lawgiver").

10. See John 10:30 ("I and my Father are one").

11. The Church of Jesus Christ of Latter-day Saints, "Organizational Structure of the Church," LDS Newsroom, http://www.mormonnewsroom.org/topic/ organizational-structure-of-the-church.

12. Thomas S. Monson, "The Sustaining of Church Officers," Ensign 37 (May 2007): 4, available at https://www.lds.org/general-conference/2007/04/the -sustaining-of-church-officers.

13. Doctrine and Covenants 1:38 ("What I the Lord have spoken, I have spoken, and I excuse not myself; and though the heavens and earth pass away, my word shall not pass away, but shall all be fulfilled, whether by mine own voice or by the voice of my servants, it is the same"); Doctrine and Covenants 21:5 ("For his word ye shall receive, as if from mine own mouth, in all patience and faith").

14. For a list of over forty scriptural references, see "Prophets, Rejection of," in Topical Guide, available at http://www.lds.org/scriptures/tg/prophets -rejection-of (providing references from the Bible, Book of Mormon, Doctrine and Covenants, and Pearl of Great Price).

15. The Church of Jesus Christ of Latter-day Saints, "Approaching Mormon Doctrine," LDS Newsroom (May 4, 2007), http://www.mormonnewsroom .org/ldsnewsroom/eng/commentary/approaching-mormon-doctrine ("With 
policies, the practical rules of administration, as discussed below in part $1 \mathrm{~B}$ on canon. They determine the canon of the Church, and any purported change in doctrine and churchwide policy must come from them.

While the Apostles set forth the law for the entire Church, regional leaders such as Area Seventies, stake presidents, and bishops interpret and apply that law for those over whom they have stewardship. ${ }^{16}$ The stewardship of each lower-level authority is defined by the priesthood keys each leader holds. ${ }^{17}$ The keys are vested in a strict vertical lineorder format and give specific stewardship to those upon whom the keys are conferred. ${ }^{18}$ Bishops, stake presidents, and regional authorities may always seek counsel from the priesthood leader above them in the line of authority. Nonetheless, the emphasis is on the ability of local leaders to receive the personal revelation necessary to adjudicate questions that

divine inspiration, the First Presidency ... and the Quorum of the Twelve Apostles ... counsel together to establish doctrine"); see also Nathan Oman, "A Defense of the Authority of Church Doctrine," Dialogue 40 (Winter 2007): 1 (defending the concept of authority in the Church on the basis of covenant, divine involvement, and community participation). Although the Church clearly states where doctrine comes from, "distinguish[ing] doctrine from beliefs, teachings, or policies" is not so straightforward. Loyd Ericson, "The Challenges of Defining Mormon Doctrine," Element 3 (Spring \& Fall 2007): 69.

16. This pattern is similar to common law legal systems in which there is a high court with supreme jurisdiction and lower courts with progressively smaller geographic areas and corresponding jurisdiction. Within their stewardship, priesthood leaders are common law judges in that they both interpret the law from canon and higher authority and then state their own conclusions, which become binding in their jurisdiction unless overturned by a higher authority.

17. Russell M. Nelson, "Keys of the Priesthood," Ensign 35 (October 2005): 40, available at http://www.lds.org/ensign/2005/10/keys-of-the-priesthood. "Those keys refer to the right to preside over priesthood authority in the name of the Lord Jesus Christ. Keys carry the right to preside over a local organization of the Church, such as a stake, a ward or branch, a mission or district, a priesthood quorum, or a temple."

18. See Joseph Fielding Smith, comp., Teachings of the Prophet Joseph Smith (Salt Lake City: Deseret Book, 1972), 21. "The president of the church is the only person on earth authorized to exercise all priesthood keys. But through his authority different keys are delegated to individuals when they are called and 'set apart' to specific positions of priesthood leadership and responsibility." Lee Tom Perry and others, "Organization: Contemporary Organization," in Encyclopedia of Mormonism, ed. Daniel H. Ludlow, 4 vols. (New York: Macmillan, 1992), 3:1044. 
arise within their stewardship. ${ }^{19}$ This means that local leaders should promulgate the same doctrine and churchwide policies, or law, throughout the Church, but the focus, style, or particular applications may vary through the exercise of stewardship in different geographical regions, or even as leadership in a certain area changes.

With respect to an individual in the Church, the most critical lowerlevel lawgiver is the bishop. ${ }^{20}$ The bishop acts as a judge as well as an advocate for the individual in cases involving higher authorities, if necessary. The bishop is a lawgiver who can adapt, as well as interpret, guidelines and procedures of general application for those in his stewardship; he is also a lawgiver of specific requirements for an individual who is in the process of seeking repentance. ${ }^{21}$ An individual may also be subject to the policies of the rotating lay leader of a particular organization within the local Church unit.

19. Doctrine and Covenants 128:11: "For him to whom these keys are given there is no difficulty in obtaining a knowledge of facts in relation to the salvation of the children of men." This concept of local inspiration is explained by Boyd K. Packer, "Principles," Ensign 15 (March 1985): 8, available at http:// www.lds.org/ensign/1985/03/principles ("If you do not know the principles-by principles I mean the principles of the gospel, the doctrines, what's in the revelations-if you do not know what the revelations say about justice or mercy, or what they reveal on reproof or forgiveness, how can you make inspired decisions in those difficult cases that require your judgment? ... There are principles of the gospel underlying every phase of Church administration. These are not explained in the handbooks. They are found in the scriptures. They are the substance of and the purpose for the revelations. . . Now, listen carefully. I do not imply that you should ignore the handbooks or manuals, not for one minute would I say that. What I do say is this: there is a spiritual ingredient not found in handbooks that you must include in your ministry if you are to please the Lord. . . . The prophet Joseph Smith gave us the key. He said, with reference to administration, 'I teach them correct principles, and they govern themselves"').

20. See Bruce C. Hafen, "Disciplinary Procedures," in Ludlow, Encyclopedia of Mormonism, 1:386 ("Because bishops are primarily concerned with the spiritual development of each member, they have wide discretion to make judgments and to give the counsel most likely to assist the member's spiritual progress and, where needed, the member's repentance"). Cheryl B. Preston, "An Itty-Bitty Immunity and Its Consequences for The Church of Jesus Christ of Latter-day Saints: A Response to Professors Lupu and Tuttle," BYU Law Review (2004): 1978-79 (noting the role of and relationship among local leaders).

21. Using the legal analogy, a bishop acts as all three branches of government, but all of his decisions are subject to appeal. 
At another level, the family is a unit of the Church, and parents are the lawgivers within their family. ${ }^{22}$ The concept of stewardship finally flows down to the individual, who is ultimately responsible for his or her own spiritual standing and relationship with Christ. Individuals are encouraged to read scriptures, pray, and seek personal revelation before making decisions. In this sense, individuals are "lawgivers" to themselves, as they interpret, apply, and follow the law that has been promulgated by lawgivers in other capacities. Members of the Church are taught that they should strive to have personal confirmation of the truth in a relationship with God that is unmediated by anyone else.

Not everyone called to positions in the Church involving lawgiving remains faithful and acts without guile. Because it is "the nature and disposition of almost all men, as soon as they get a little authority, as they suppose, [to] immediately begin to exercise unrighteous dominion" (D\&C 121:39), the Doctrine and Covenants specifically instructs that the "rights of the priesthood are inseparably connected with the powers of heaven, and that the powers of heaven cannot be controlled nor handled only upon the principles of righteousness" (D\&C 121:36). The offices in the Church's vertical structure are inspired, but the power depends on righteousness.

2. Latter-day Saint Canon. The second vertical structure of the Church is the written canon. The term "canon" derives from Greek kanon, literally meaning a reed or cane, and came to be understood in Latin as a measuring rod, rule, model, or standard.

Latter-day Saint canon is not a simple concept, especially for persons of other faiths who see the scriptures as the ultimate or final source of written truth. ${ }^{23}$ The canon of the Church-in fact, the entire Latter-day

22. See Doctrine and Covenants 68:25 ("And again, inasmuch as parents have children in Zion, or in any of her stakes which are organized, that teach them not to understand the doctrine of repentance, faith in Christ the Son of the living God, and of baptism and the gift of the Holy Ghost by the laying on of the hands, when eight years old, the sin be upon the heads of the parents"). See also The First Presidency and Council of the Twelve Apostles of The Church of Jesus Christ of Latter-day Saints, "The Family: A Proclamation to the World" (1995), available at http://www.lds.org/family/proclamation ("Parents have a sacred duty to rear their children in love and righteousness, ... to teach them to love and serve one another, to observe the commandments of God and to be law-abiding citizens wherever they live").

23. This difficulty is discussed by Robert L. Millet, who also gave a list of sources of doctrine, which are very similar to the sources discussed below. Robert L. Millet, "What Do We Really Believe?" in Discourses in Mormon Theology, 
Saint experience-must be viewed against the backdrop of continuing revelation: at the core, one cannot subscribe to the Latter-day Saint faith without believing that communication with Deity continues as in ancient times. ${ }^{24}$ Thus, this concept of canon differs slightly from that of most religions, even though it similarly begins with scriptures and goes through various levels of authoritative and semi-authoritative texts. Latter-day Saint scripture may be amended with latter-day prophetic declarations, and thus the LDS canon envisions a less rigid and historically fixed documentation.

Some contend that the changeable nature of Latter-day Saint canon necessarily means that it cannot claim to contain ultimate and absolute truth. ${ }^{25}$ However, members are encouraged to receive from God a personal testimony of truth through the authority of the Church-its leaders and scriptures. With this testimony, Latter-day Saints believe that Mormon doctrine has an "epistemological advantage" over their own judgments and so are willing to regard the Church's teachings as authoritative. $^{26}$

ed. James M. McLachlan and Loyd Ericson (Salt Lake City: Greg Kofford Books, 2007), 266-67 ("In determining whether something is a part of the doctrine of the Church, we might ask: is it found within the four standard works and/or within official declarations or proclamations? Is it taught or discussed in general conference or other official gatherings by general Church leaders today? Is it found in the general handbooks or approved curriculum of the Church today? . . . The content of the temple endowment today would certainly be considered a part of the doctrine of the Church").

24. "We believe all that God has revealed, all that He does now reveal, and we believe that He will yet reveal many great and important things." Article of Faith 9; see also Joseph Smith-History 1:16-20, 49-50 (hereafter cited as JS-H); Doctrine and Covenants 90:12-14 (indicating that from time to time Joseph Smith received revelations to unfold the mysteries of the kingdom).

25. See, for example, Ericson, "Challenges of Defining Mormon Doctrine," 8o-85; but compare Robert L. Millet, "Defining Doctrine: A Response to Loyd Ericson," Element 5 (Spring 2009): 1 ("Unless one is caught up with a notion of prophetic or apostolic infallibility, he or she is not greatly troubled by such an idea [of continuing revelation]").

26. Nathan Oman, "Truth, Doctrine, and Authority, Element 5 (Spring 2009): 13. In a recent general conference address, President Dieter F. Uchtdorf acknowledged that "there have been times when ... leaders in the Church have simply made mistakes," but he then concluded the thought by assuring members of the Church that "no decision of significance affecting this Church or its members is ever made without earnestly seeking the inspiration, guidance, and approbation of our Eternal Father." Dieter F. Uchtdorf, "Come, Join with Us," 
a. Scriptures. Any discussion of canon must begin with the scriptures, which are referred to as the "standard works" and consist of the King James Version of the Bible, the Book of Mormon, the Doctrine and Covenants, and the Pearl of Great Price. In the language of law, the standard works perform the function of a Constitution, a foundational document to which amendments may be added. Elder Dallin H. Oaks, a former lawyer, law professor, and judge, explains: "Because of our belief in continuing revelation, we Latter-day Saints maintain that the canon (the authoritative body) of scriptures is open. In fact, the scriptural canon is open in several ways, and continuing revelation is crucial to each of them." 27 Thus, the LDS canon is based on the scriptures, but they are situated within the context of ongoing revelation.

The Church couches its beliefs regarding scriptural canon in qualifiers: "We believe the Bible to be the word of God, as far as it is translated correctly." 28 The preamble to the Book of Mormon contains this caveat: "If there are faults they are the mistakes of men." ${ }^{29}$ Although the Church teaches that the "the Book of Mormon [is] the most correct of any book

Ensign 43 (November 2013): 22-23, available at www.lds.org/ensign/2013/11/ saturday-morning-session/come-join-with-us.

27. Dallin H. Oaks, "Scripture Reading and Revelation," Ensign 25 (January 1995): 7, available at http://www.lds.org/ensign/1995/o1/scripture-reading-and -revelation.

28. Article of Faith 8 (emphasis added). See also Robert J. Matthews, "Joseph Smith Translation of the Bible (JST)," in Ludlow, Encyclopedia of Mormonism, 3:764 ("When [Joseph Smith] said the Bible was not translated correctly, he not only was referring to the difficulties of rendering the Bible into another language but he was also observing that the manuscripts ... have suffered at the hands of editors, copyists, and revisionists").

29. Book of Mormon, title page. According to Joseph Smith, "the title-page of the Book of Mormon is a literal translation, taken from the very last leaf, on the left hand side of the collection or book of plates, which contained the record which has been translated, the language of the whole running the same as all Hebrew writing in general; and that said title page is not by any means a modern composition, either of mine or of any other man who has lived or does live in this generation." Joseph Smith Jr., History of The Church of Jesus Christ of Latterday Saints, ed. B. H. Roberts, 2 d ed., rev., 7 vols. (Salt Lake City: Deseret Book, 1971), 1:71 (hereafter cited as History of the Church). The original 1830 printing of the Book of Mormon included this title page, and it has been part of the Book of Mormon ever since. See Daniel H. Ludlow, "The Title Page," in First Nephi: The Doctrinal Foundation, ed. Monte S. Nyman and Charles D. Tate Jr. (Provo, Utah: BYU Religious Studies Center, 1988), 19-22. 
on earth," ${ }^{30}$ it is not a perfect book. Saints recognize that between the word of God and the written work is a human scribe-saintly, perhaps, but still human. Thus, according to Elder Oaks, "God will give new revelations on the meaning of scriptures previously canonized, meanings that were not evident in earlier times.... We believe that the scriptures, which are the revelations of the past, cannot be understood without openness to the revelations of the present." ${ }^{31}$ The scriptures unfold, as do Jesus's parables, only when we develop "ears to hear." ${ }^{32}$ In addition, entirely new material can be added to scriptural canon through the process discussed below.

b. Latter-day Prophetic Declarations. Although the scriptures are the "standard," official declarations by the First Presidency and Quorum of the Twelve Apostles, made collectively in their official capacities as prophets, seers, and revelators, are also canon, or at least very closely associated with the canon, although in different form. ${ }^{33}$ This is true even if such declarations are not included in printed scriptures, although some are.

In their roles as prophets, seers, and revelators, the First Presidency and the Quorum of the Twelve have, as a collective, "from time to time issued formal written proclamations, declarations, letters, and various

30. Book of Mormon, introduction (emphasis added). President Spencer W. Kimball taught: "This inspiring book was never tampered with by unauthorized translators or biased theologians but comes to the world pure and directly from the historians and abridgers." Spencer W. Kimball, The Teachings of Spencer W. Kimball: Twelfth President of The Church of Jesus Christ of Latter-day Saints, ed. Edward L. Kimball (Salt Lake City: Bookcraft, 1998), 133.

31. Oaks, "Scripture Reading and Revelation," 7.

32. This phrase with respect to Jesus's parables appears in Matthew 11:15, 13:9, 43; Mark 4:9, 23, 7:16; Luke 8:8, 14:35. See part 2C.

33. Although most Latter-day Saints would initially identify the "canon" as the standard works, in practice the pronouncements of the fifteen prophets, seers, and revelators are very similar to canon. "The First Presidency performs the central and authoritative role of receiving revelation and establishing policies and procedures for the Church.... The Council, or Quorum, of the Twelve Apostles is a quorum 'equal in authority and power' to the First Presidency, meaning that when the First Presidency is dissolved (which occurs upon the death of the President of the Church) the Council of the Twelve exercises all of the power and authority previously reserved to the First Presidency until a new First Presidency is organized (D\&C 107:23-24)." Perry and others, "Organization: Contemporary Organization," 3:1046. The Church has stated that Church doctrine is established by the Council of the Twelve and the First Presidency, and that doctrine "is consistently proclaimed in official Church publications." The Church of Jesus Christ of Latter-day Saints, "Approaching Mormon Doctrine." 
public announcements." ${ }^{34}$ Most of these documents have not yet been incorporated into the body of scriptures through the prescribed formal approval action necessary to codify them in the standard works. Two declarations have been subject to that process and are now included in more recent editions of the standard works. ${ }^{35}$ The process requires them to be proposed to the general membership and approved by "common consent." ${ }^{36}$ Other declarations, such as "The Family: A Proclamation to the World" ${ }^{37}$ issued in 1995, remain in declaration form.

In addition to official declarations, the First Presidency and the Quorum of the Twelve Apostles approve temple ceremonies, which are not published or available outside a Latter-day Saint temple, but are clearly a form of oral canon ${ }^{38}$-binding and authoritative.

34. Robert J. Matthews, "Proclamations of the First Presidency and the Quorum of the Twelve Apostles," in Ludlow, Encyclopedia of Mormonism, 3:1151. These formal pronouncements are similar to decisions from the supreme court of a jurisdiction: in that they are not subject to appeal and are final until overturned by that same body.

35. Although LDS canon is open, it is not without boundaries, and it is not subject to willy-nilly revision. See generally, John W. Welch and David J. Whittaker, "Mormonism's Open Canon: Some Historical Perspectives on Its Religious Limits and Potentials," paper presented at the Annual Meeting of the American Academy of Religion and the Society of Biblical Literature, Atlanta, November 24, 1986, copy on file with author and available as a Preliminary Report in 1987, in L. Tom Perry Special Collections, Harold B. Lee Library, Brigham Young University, Provo, Utah. With respect to material added to the standard works, procedures for canonization restrict the ability of new works to be accepted into the tenets of the faith. See Doctrine and Covenants, Official Declaration-2 (exemplifying this process). For a text to be canonized, it must be first unanimously accepted by the First Presidency and the Quorum of the Twelve Apostles, and then presented to the general membership of the Church, who must vote to sustain the decision of the leadership by common consent. In addition, declarations of the modern-day prophet that are a form of canon are rare and come published over the signatures of all fifteen of those who are ordained as prophets, seers, and revelators. See note 14 and accompanying text.

36. A vote of the members held during meetings.

37. See note 24.

38. See Kathleen Flake, “'Not to be Riten': The Mormon Temple Rite as Oral Canon," Journal of Ritual Studies 9 (Summer 1995): 1-7. For general information on temple ceremonies, see Boyd K. Packer, The Holy Temple (Salt Lake City: Deseret Book, 1980); John A. Widtsoe, "Looking toward the Temple," Ensign 2 (January 1972): 56, available at http://www.lds.org/ensign/1972/o1/looking-toward-the -temple. "Endowed with Covenants and Blessings," Ensign 25 (February 1995): 
Not all collective statements of the First Presidency and Quorum of the Twelve are official proclamations or declarations. Some are administrative or deal with a transitory issue. Deciphering which of their statements are "official" in the sense of being like canon depends on their form and the method of delivery. In any event, any statement issued by this body is at least highly authoritative.

c. Churchwide Policies. Legal practitioners and scholars know that U.S. law does not stop at the Constitution or anywhere near it. Those of us who have practiced tax law know that the Constitution gives Congress the power to tax. Congress gives us the Internal Revenue Code and establishes the Treasury Department. The Treasury Department gives us regulations and the Internal Revenue Service (IRS). The IRS generates revenue rulings, which have general application and are binding with respect to all taxpayers. Moreover, the IRS generates private letter rulings, which are binding only with respect to the taxpayer who requested them. And then, of course, the courts at every level become involved in interpreting all of these. Similarly, in the Church, there are various authoritative publications below the level of canonized scripture.

d. Handbooks and Church Directives. Next to the canon of scriptures and Official Declarations, Church handbooks and letters from the First Presidency may be considered the most authoritative Church publications. Church Handbooks 1 and 2 include statements of policy and procedure. The first volume is reserved for bishoprics and stake presidencies; the second volume covers all other organizations and auxiliaries. For instance, the policies regarding musical numbers in Church meetings are outlined in volume two of the handbook. ${ }^{39}$

e. Correlated Church Publications. Below the Handbooks and First Presidency letters are "correlated" Church publications that are prepared under the direction of the various Church departments and approved by the Correlation Review committees, ${ }^{40}$ which include various members of the Quorum of the Twelve Apostles. At this level, these publications include "(1) materials related to the curriculum, such as lesson manuals, ... ; (2) magazines; (3) administrative documents,

38, available at http://www.lds.org/ensign/1995/o2/endowed-with-covenants -and-blessings.

39. See "Music," in Handbook 2: Administering the Church (Salt Lake City: The Church of Jesus Christ of Latter-day Saints, 2010), 14.1, available at https:// www.lds.org/handbook/handbook-2-administering-the-church/music.

40. Dean L. Larsen, “I Have a Question," Ensign 7 (August 1977): 38, available at http://www.lds.org/ensign/1977/08/i-have-a-question. 
such as . . leadership training materials, organizational guidelines and bulletins, etc.; and (4) missionary discussions, tracts, and support materials." ${ }^{41}$ Correlated materials are easily identified because they are the only publications that "carry the designation 'Copyright (c) Corporation of the President of The Church of Jesus Christ of Latter-day Saints." 42 Books written by members of the Quorum of Twelve Apostles and other General Authorities are generally not considered official in this sense; however, a "careful selection" of books not published by the Church or created through the Correlation process have been approved before by the First Presidency and the Twelve to be placed in Church meetinghouse libraries. ${ }^{43}$ Moreover, a speech given by any of the fifteen members of the First Presidency and Quorum of the Twelve Apostles at a Latter-day Saint semiannual general conference, which proceedings are later published, is also highly authoritative but is not canonized.

f. Semi-Authoritative Texts. Below "authoritative" texts, as described in the prior subsection, are numerous nonfiction books and other source materials, published either through Church-owned Deseret Book Company or under the auspices of Brigham Young University (BYU). Because these publishers are closely connected to the Church, their editors are unlikely to take manuscripts that are very controversial. While the Church makes no official endorsement of these works, other than allowing their publication by a Church-owned publisher, many members see these publications as higher in doctrinal reliability than others. Nonetheless, these are not official publications and not considered doctrinal.

The list of these semi-authoritative sources includes the publications of BYU's Religious Studies Center, whose publications on modern Mormonism are primarily apologetic rather than strictly scholarly, ${ }^{44}$

41. Larsen, "I Have a Question," 38.

42. Larsen, "I Have a Question," 38.

43. Larsen, "I Have a Question," 38. These items not published by the Church are placed in church libraries by the wards or branches and can be found at store.lds.org. The Church of Jesus Christ of Latter-day Saints, "Meetinghouse Library Materials," LDS.org, https://www.lds.org/callings/sunday-school/leader -resources/meetinghouse-library-materials.

44. See Brigham Young University Religious Studies Center, "Frequently Asked Questions," http://rsc.byu.edu/frequently-asked-questions. "The Religious Studies Center is the research arm of Religious Education at Brigham Young University. Established in 1975 under the direction of Dean Jeffrey R. 
although many are sophisticated apologetics; ${ }^{45}$ the Neal A. Maxwell Institute for Religious Scholarship; ${ }^{46}$ and BYU Studies, a BYUsponsored publisher of peer-reviewed articles and books. ${ }^{47}$

3. The Absence of Official Scholarly Interpreters. Most organized religions have lawmakers and a settled canon; the Latter-day Saint faith also has a kind of canon, even if somewhat fluid. The main vertical distinction of the Church is its lack of the common third pillar: official interpreters. The Church has no official scholarly tradition that has become a recognized "body of theology" and no official "methods of interpretation."

While the Church puts vast resources into education, it does not provide education of a purely theological nature to produce professional theologians. The Church also does not invest much in the way of direct financial support for theological scholars in its university system or for the few scholars in the Church's historical department. ${ }^{48}$ With respect to this limited group, much of their work is apologetic and documentary history rather than theoretical exploration.

The Church provides religious education in the form of seminary for high school students, religion classes for BYU students, and institute classes for other college-aged members. These classes place emphasis on the spiritual conversion of the students and on motivating students to conform their behavior to Latter-day Saint standards. ${ }^{49}$ The materials

Holland, the center has funded research and published groundbreaking works on Latter-day Saint scripture, doctrine, history, and culture."

45. See http://oxforddictionaries.com/definition/english/apologetic?q =apologetic for a definition of apologetic ("constituting a formal defense or justification of a theory or doctrine").

46. See Neal A. Maxwell Institute for Religious Scholarship, http://maxwell institute.byu.edu.

47. See BYU Studies, "Mission, Purpose, and History of BYU Studies," https://byustudies.byu.edu/Mission.aspx. "BYU Studies is dedicated to publishing scholarly religious literature ... that is qualified, significant, and inspiring."

48. For information on some of the scholars working there, see, for example, Mormon History Association 48th Annual Conference program available at http://mormonhistoryassociation.org/pdf/2013-conference-program.pdf; and The Joseph Smith Papers Project Team and National Advisory Board, listed at http://josephsmithpapers.org/projectTeam.

49. For example, the institute manual on the Old Testament states, "This course of study is designed to give you the opportunity to come to know the God of the Old Testament in an intimate, personal, and powerful way. . . . From these accounts we can learn much about how to come unto Christ." Old 
are compilations from the canon and semi-authoritative statements of the First Presidency and Quorum of the Twelve Apostles cited earlier. ${ }^{50}$ Many of the teachers of the required college-level religion classes are Latter-day Saint professors from other disciplines at the university, rather than from Religious Education. Although active on the campus of BYU in Utah, Religious Education ${ }^{51}$ does not offer a major course of study or grant undergraduate or graduate degrees. The emphasis in Religious Education has been the practical application of religious principles in the lives of students, although that is changing to some extent. ${ }^{52}$

The absence of a theological branch in the Church is unsurprising if one considers the concept of continuing revelation. Churches that derive doctrine from fixed and unchanging canon need to have a way to interpret that canon. The Latter-day Saint faith, on the other hand, has a flexible canon that leadership can change or add to. ${ }^{53}$

Testament Student Manual Genesis-2 Samuel (Salt Lake City: The Church of Jesus Christ of Latter-day Saints, 2003), v.

50. Manuals include, in addition to background information, "interpretive and prophetic commentary on the most important passages and some of the difficult passages." Old Testament Student Manual Genesis-2 Samuel, vi.

51. Note that it is not named the College of Theology or even the College of Religion. It is not officially a college but is a support unit within the university that offers courses in Church history, doctrine, and scriptures.

52. Scholarship coming out of the Religious Education and through Churchsponsored conferences is gaining respect with international New Testament scholars. See Marin Decker, "Speakers Take Scholarly Look at Life of Christ," Deseret Morning News, Utah County edition, March 28, 2005, B2, available at http://deseretnews.com/dn/view/o,1249,600121845,00.html. Similarly this scholarship is being noticed by American religious historians. See Carrie A. Moore, "Topic: Joseph Smith," Deseret Morning News, Utah County edition, October 1, 2005, A1, available at http://deseretnews.com/dn/view/o,1249,615154512,0o.html (quoting scholar Robert K. Millet: "There is ... a greater interest in inviting [LDS scholars] into broadening religious conversations"). A former dean of Religious Education, Robert K. Millet, stated, "We've done a good job speaking of faith; [the Church-owned publisher] pumps out books every year. But now, we're actually ... speaking the language of scholarship." Decker, "Speakers Take Scholarly Look at Life of Christ," B2.

53. See Millet, "What Do We Really Believe?" 277 ("The fact that God continues to speak through his anointed servants; the fact that He, through those servants, continues to reveal, elucidate, and clarify what has already been given; and the fact that our canon of scripture is open, flexible, and expanding-all of this militates against what many in the Christian world would call a systematic theology"). 
Thus, in the Church there are no professional theologians in the sense of trained scholars attempting to systematize a comprehensive, closed, rational, scholarly, or complex statement of Latter-day Saint religious belief and doctrine, using traditional scholarly methodology comparable to that found in many Christian churches and in Judaism. On the other hand, every Latter-day Saint member is a sort of aspiring theologian. Members of the Church engage in extensive "theology" in the sense of "talking about God" and seeking to conform their lives to Church principles. "Every member of the Church ... has the duty to pray daily, study the scriptures, [and] draw close to the Savior." ${ }^{4}$ To ensure that "Latterday Saint children are taught from their youth to know the scriptures," mothers are advised of the need to study religion. "We want our homes to be blessed with sister scriptorians" who "become scholars of the scriptures-not to put others down, but to lift them up!"56

As with any text, the canon or doctrine of the Church does not unambiguously answer all questions in all situations. Members and leaders alike need to engage in some interpretation. Nathan Oman has suggested that the way members interpret doctrine is by surveying the content, history, and purpose of promulgated doctrine and using all of this to tell a comprehensive story to determine what should be done in certain instances. ${ }^{57}$ In this way, all Church members make up for the lack of a third pillar as they engage in a relatively sophisticated interpretation analysis, albeit without uniform methods of interpretation.

In summary, the Latter-day Saint canon comprises the "law" of the Church and includes the standard works, similar in status and authority to the U.S. Constitution. This canon may be expanded or clarified by modern-day revelation, and like the complex structure of laws that support the Constitution, the Church's standard works are supported by laws of lesser authority such as the Church handbooks and directives, correlated Church publications, and semi-authoritative texts.

54. Joseph B. Wirthlin, "Let Every Man Learn His Duty," Ensign 10 (November 1980): 70, available at http://www.lds.org/ensign/1980/11/let-every-man -learn-his-duty.

55. Boyd K. Packer, "Guided by the Holy Spirit," Ensign 41 (May 2011): 30, available at http://www.lds.org/ensign/2011/05/guided-by-the-holy-spirit.

56. Teachings of Presidents of the Church: Spencer W. Kimball (Salt Lake City: The Church of Jesus Christ of Latter-day Saints, 2006), 221.

57. Nathan B. Oman, "Jurisprudence and the Problem of Church Doctrine," Element 2 (Fall 2006): 1. 
Two vertical structures or pillars exist in the form of Church canon in union with Church lawmakers. The lack of a third, professional theologians and scholarly theological method, actually allows the remaining vertical and horizontal elements of the Church to combine in a unique way, discussed below in part 2.

As described by Frank Lloyd Wright, the vertical structure does not achieve the "spiritual union" of a living whole without all things being in unity. The vertical and horizontal forms of the Church strike the necessary balance to create unity with the Church's function. While the vertical structure is necessary to organize a worldwide Church with more than fifteen million members, ${ }^{58}$ the horizontal elements give the Church the personal and equal forum for meeting the spiritual principles discussed in part 2. The next part, 1B, describes these horizontal elements.

\section{B. LDS Horizontal Form}

This part will discuss briefly the horizontal features of the structure of the Church and how they connect and meld with the twin vertical poles discussed in part 1A. The horizontal structures include the limited-term, lay leadership; the role of counselors and councils; and the use of peer teaching and discussions.

1. Lay Leadership. One extraordinary feature of institutional Mormonism is its lay leadership. ${ }^{59}$ Units of the Church all over the world are run by local bishops or branch presidents, stake or district presidents, and Area Seventies, none of whom are trained theologians or even required to have attended college. Sometimes they also have no prior formal leadership experience, little training in the Church, ${ }^{60}$ and a short time in which to learn on the job because their tenure as leaders is typically limited to about five years. Some of the local leaders in growth

58. The Church of Jesus Christ of Latter-day Saints, "Facts and Statistics," Newsroom, http://www.mormonnewsroom.org/facts-and-stats (showing Church membership as of July 2014 to be $15,082,028$ ).

59. For a discussion of the characteristics and duties of LDS priesthood leaders, see Preston, "Itty-Bitty Immunity," 1976-78.

6o. William G. Dyer, "Leadership Training," in Ludlow, Encyclopedia of Mormonism, 2:818 ("Sometimes [a person] is appointed to a position to which he has had no training, as the bishop or stake president follows the impressions of the Spirit in extending calls to service"); Don M. Pearson, "Bishop," in Ludlow, Encyclopedia of Mormonism, 1:117 (noting that leaders are chosen based on revelation and the characteristics considered are "testimony, judgment, commitment, and charity toward ward members"). 
areas have not even been members of the Church for extended periods of time.

There are prerequisites to holding certain leadership positions within the Church beyond living in accordance with LDS spiritual principles. For positions in the vertical structure described above, members must be ordained to the priesthood, which is conferred only on males, ${ }^{61}$ and they must be or have been married, meaning that not all faithful members have equal opportunity to serve in every calling. However, this does not negate the uniqueness of the LDS structure, where leaders are chosen without respect to education, social status, prior positions, or length of membership. In this respect it is unlike other religious and legal institutions.

The second feature of LDS Church leadership is that most of the leaders live and work outside the Church. In the LDS faith, the vast majority of leaders, including all local leaders, are part time and live in the same neighborhoods as other members, working other jobs to support their families. ${ }^{62}$ They are not paid by the Church and face the same financial challenges as other members. ${ }^{63}$ There are a few exceptions: the Quorum of the Twelve and Presidency of Church have lifetime appointments; the First Quorum of Seventy, who assist the Quorum of the Twelve in their duties, generally serve until age seventy; and the Second Quorum of the Seventy, who serve for three to five years. These general, churchwide priesthood authorities (just over one hundred) ${ }^{64}$ are financially supported and discontinue any other employment. A few other leaders, such as mission presidents and other central administrators, serve full time for three to five years and also receive a modest financial stipend.

In contrast to LDS leaders, most priests and pastors of other organized religions are paid, typically receiving a modest salary ${ }^{65}$ and perhaps

61. Preston, "Itty-Bitty Immunity," 1976.

62. Pearson, "Bishop" ("A bishop is a lay minister and receives no monetary compensation for his services. Like other local Church officers, he must maintain himself and his family through normal employment").

63. See also Boyd K. Packer, "The Bishop and His Counselors," Ensign 29 (May 1999): 58, available at http://www.lds.org/ensign/1999/05/the-bishop-and -his-counselors ("The bishopric must have time to make a living and time for their own families").

64. See The Church of Jesus Christ of Latter-day Saints, "General Authorities" (organizational chart), http://www.lds.org/church/leaders.

65. Colleen Reinhart, "Salary of Pastors," eHow, http://www.ehow.com/ info_7759160_salary-pastors.html ("The annual income for a pastor is highly 
a parsonage or a housing allowance. I do not suggest paid pastors are less sincere or that paying full-time ministers is necessarily inconsistent with Christian doctrine. The point is that having unpaid clergy in the LDS faith contributes to its horizontal structure to the extent that being unpaid and living like other members vastly reduces the distance between the leader and member.

A third difference is the length of service. Other than the slim exceptions mentioned above, leaders in the Church serve for very limited periods and then the position rotates to another lay member. Additionally, a person seldom receives the same appointment twice. The frequent rotation from leader to follower is very effective in dispersing power and preventing legacy calcifications in the system.

These three characteristics of LDS lay leadership-an absence of education or similar status requirement for leadership positions, unpaid clergy, and frequent rotation of assignments-all reduce the gap between Church members and their leaders, thus adding a horizontal element to the Church. One way in which the LDS leadership is actually more vertical than other religious organizations is found in its selection process. Leaders in the Church, while ratified by "common consent," are appointed and do not purport to represent a majority view of the congregation. ${ }^{66}$ As discussed in part 2, the combination of these vertical and horizontal structures is beneficial to the functions of the Church.

2. Councils and Auxiliaries. The Church benefits from a second web of lay leadership in the form of members acting as counselors, councils, committees, and auxiliary officers with various functions. These advise the leaders and assist in carrying out the leaders' responsibilities.

Elder M. Russell Ballard acknowledged this key feature of Church composition: "When we support one another in Church councils, we begin to understand how God can take ordinary men and women and make of them extraordinary leaders. The best leaders are not those who work themselves to death trying to do everything single-handedly; the

variable, according to data from the Bureau of Labor Statistics. The median annual income for religious clergy, as of 2010 , is $\$ 42,950$, but there is a broad pay scale for these professionals. Some pastors get paid far more than average while others receive far less. The lowest-paid 10 percent made just $\$ 11.03$ per hour in 2009, equivalent to an annual salary of $\$ 22,940$ per year. At the high end, pastors made an average of $\$ 36.21$ per hour, or $\$ 75,320$ per year").

66. This is a key difference between the LDS structure and modern legal structures, but democratic systems have problems of their own, such as unwanted influence through money, power, and personal connections. 
best leaders are those who follow God's plan and counsel with their councils." ${ }^{97}$ Councils and committees are found at all levels of administration-the Quorum of the Twelve Apostles acts as a council; a high council is used on the stake level; and on the ward level, there is the priesthood executive committee, the ward welfare committee, and the ward council. ${ }^{68}$ Auxiliaries may also set up committees and councils. In addition to councils, officers at all levels have two counselors who advise and assist them.

Auxiliary organizations-the Primary, youth programs, Sunday School, and Relief Society-address the particular issues of these groups. These organizations are vertically similar in internal structure to the twin columns of the whole Church described above, with a churchwide general president for each organization down to local ward president, with two counselors, and with manuals and particularized publications. These organizations are under the stewardship of the local bishop, who coordinates all local affairs.

Councils provide a way through which members of the Church who cannot hold priesthood leadership positions can still participate and influence the affairs of the Church in a positive way. ${ }^{69}$ Also, because of the sheer volume of positions available, a large percentage of a local Church unit is involved in leadership and counseling functions at any one time. This connection between the vertical priesthood leader structure and the horizontal member involvement creates a continuity that melds these elements together, as Frank Lloyd Wright would describe: "Here [is] the direct means of expression of the more spiritual idea that form and function are one ... the expressive flow of continuous surface." 70

67. M. Russell Ballard, "Counseling with Our Councils," Ensign 24 (May 1994): 26, available at http://www.lds.org/ensign/1994/05/counseling-with-our -councils. See also First Presidency and Council of the Twelve Apostles, "The Family: A Proclamation to the World."

68. Ballard, "Counseling with Our Councils," 26.

69. See Ballard, "Counseling with Our Councils," 26 (telling stories of council members, particularly women, influencing the decision of the bishop in problems the ward was facing).

70. Wright, Autobiography, 146: "Plasticity may be seen in the expressive flesh-covering of the skeleton as contrasted with the articulation of the skeleton itself. If form really 'followed function'-as the Master declared-here was the direct means of expression of the more spiritual idea that form and function are one: the only true means I could see then or can see now to eliminate the separation and complication of cut-and-butt joinery in favor of the expressive flow of continuous surface. Here, by instinct at first-all ideas germinate-a 
3. Peer Learning. The concept of peer learning is solidly rooted in modern scripture, as the early members of the Church were commanded to "teach one another the doctrine of the kingdom" (D\&C 88:77). This imperative is still carried out today. Sacrament meeting talks are given almost exclusively by members of the local congregation, rather than by regional or churchwide authorities, experts in religious studies, or professional preachers. Almost every member of the congregation has a turn at the podium. In addition, once a month, spontaneous volunteers from the congregation offer personal witnesses and bear testimony of Jesus Christ and his influence in their lives during fast and testimony meeting.

On a more personal level, gospel teachers for the adults' and children's Sunday schools and all other LDS teaching and training organizations are called from members of the congregation. Teachers are assigned to that role for short terms, typically one or two years. The job then rotates to another member of the congregation. In addition, those serving as teachers at any given time are expressly encouraged to invite class discussion. ${ }^{71}$

The Church depends on the members of local congregations to speak in services, to teach classes, and to join in class discussions; all members are expected and encouraged to be knowledgeable about the scriptural canon. The rotation of lawmakers and the participation of all members of the congregations create a horizontal structure. These horizontal features are critical to softening the inherent rigidity of the vertical forms and, combined with the absence of a type of structure common to most

principle entered into building that has since gone on developing. In my work the idea of plasticity may now be seen as the element of continuity."

71. Brent A. Barlow, "When All Have Spoken," Ensign 21 (January 1991): 28, available at http://www.lds.org/ensign/1991/o1/when-all-have-spoken ("Class participation is being emphasized more and more in Church instruction. For example ... : As a teacher you should focus on helping class members participate. ... Class members should teach and edify one another. ... Participation helps invite the Spirit into the class and motivates members to apply and live scriptural principles"). See also, for example, "Helps for the Teacher," in New Testament: Gospel Doctrine Teacher's Manual (Salt Lake City: Intellectual Reserve, Inc., 1997), vi, available at http://www.lds.org/manual/new-testament -gospel-doctrine-teachers-manual/helps-for-the-teacher ("It is more important to help class members understand and apply the scriptures than to cover all the lesson material you have prepared. If class members are learning from a good discussion, it is often helpful to let it continue rather than try to cover all the lesson material"). 
other churches, as discussed below, are critical to the melding of form and theological substance.

\section{Part 2. Form And Function Connected}

The Church's two vertical structures, discussed in part 1A, form a scaffold, providing the support needed for the Church to maintain its identity, organization, and authority for administering ordinances. These are woven together with some remarkable horizontal and communitarian forms, discussed in part $1 \mathrm{~B}$, which give the Church its vitality and its unparalleled sense of member engagement. In part 2, I will draw three important connections between LDS form or structure and its doctrinal or substantive function. I argue that the Church's form is both created by and creates certain religious practices and beliefs. While parallels may be drawn among all kinds of spiritual and practical Church functions, I am going to discuss three uniquely LDS spiritual principles that I consider key to the purpose of the kingdom on earth. I categorize them as gospel ownership, personal experience, and direct light.

\section{A. Gospel Ownership}

As detailed above, the LDS faith organizes the structure of religious learning horizontally, ${ }^{72}$ requiring everyone to teach and be taught, lead and be led, administer and be administered to. Consider this observation of non-LDS historian Mark Leone: "Whereas the audience in other Christian churches receives, more or less passively, meaning declared from the pulpit, Sunday school teacher, or other authoritative religious source, every Mormon is the preacher, teacher, exegete, and definer of meaning before an audience of peers, who a moment or a month later may switch positions with him." ${ }^{\text {.3 }}$ The LDS gospel learning experience is community based, taught by members of the congregation with a

72. Some of this horizontal structure may perhaps be described as the "marked Congregationalist tendencies that [the LDS Church] retained in some form throughout its career." Thomas F. O'Dea, The Mormons (Chicago: University of Chicago Press, 1957), 167. The Church is not congregational in the sense that the local unit is entirely self-sustaining and subject only to its own rules. But LDS local units retain in many respects their own environment and learning processes.

73. Mark P. Leone, Roots of Modern Mormonism (Cambridge, Mass.: Harvard University Press, 1979), 168. 
teacher's manual and ample class discussion. This type of teaching has many benefits that contribute to gospel ownership by members.

The Church has recently introduced a program that puts even more emphasis on discussion-based horizontal teaching and learning. The course of study for the missionary program, Preach My Gospel, is designed to be more interactive between missionary and investigator, and a new youth program is more focused on having the youth take responsibility for teaching themselves and each other.

One benefit of discussion-based teaching is that it increases motivation. The goal is to change the heart of the student. ${ }^{74}$ The student is much more likely to change to conform with the spiritual principles taught if the student internalizes, and the student is much more likely to internalize if he comes to knowledge actively, rather than merely allowing words to enter one ear and exit right out the other. ${ }^{75}$ Further, in a discussion, the student has opportunity to clear up questions that might hinder actual application of principles and to ask questions based on particular circumstances. The concept of learning through question and answer is not unique to the Church. The Socratic method, a pillar of legal teaching, ${ }^{76}$ seeks to "hone students' reasoning skills through active engagement with the teacher-or observation of another student's active engagement." 7 The process of the Socratic Method revolves around applying legal theories and doctrines to practical applications, which has led legal educators to believe that "if we want our professionals-in-training to get practice in responding to novel circumstances, this is it." ${ }^{78}$ Likewise, if we want religious students to get practice in applying gospel principles to the situations that may arise in their lives, a question and discussion method

74. See The Church of Jesus Christ of Latter-day Saints, Teaching the Gospel in the Savior's Way (Salt Lake City: Intellectual Reserve, 2012), 3.

75. See Church of Jesus Christ of Latter-day Saints, Teaching the Gospel in the Savior's Way, 7.

76. See James Stuart Murray, "Interpreting Plato on Sophistic Claims and the Provenance of the 'Socratic Method," Phoenix 48 (1994): 115; Black's Law Dictionary, abridged 7 th ed. (St. Paul, Minn.: West Group, 1999), 1122. For a description more closely analogous to the informal Socratic method employed by LDS teachers, see Anita Hamilton, "All the Right Questions," Time, March 28, 2004, 65-66, available at http://www.time.com/time/magazine/article/ 0,9171,605470,oo.html.

77. Bethany Rubin Henderson, "Asking the Lost Question: What Is the Purpose of Law School?" Journal of Legal Education 53 (2003): 48, 65.

78. D. Don Welch, "What's Going On' in the Law School Curriculum," Houston Law Review 41 (2005): 1607, 1616. 
is best. As in legal education, Church teaching is aimed at training individuals to find their own answers rather than teaching students the rules and answers. When the goal is to make spiritual "professionals" who can become like Jesus Christ, such active "process" training is particularly helpful.

A careful look at the Bible reveals that God frequently employs a question-and-answer teaching method. For instance, although he knows the answers, he asks Adam and Eve a series of questions in Genesis 3:9-13, and also Cain in Genesis 4:9-10, leading them through his questioning to acknowledge the truth of their situations. Jesus did likewise with his disciples, as in Matthew 5:13, 46-47, and 6:25. ${ }^{79}$ In addition, participation denotes individual responsibility for the subject. President Gordon B. Hinckley articulated, "The Lord expects us to think. ... That which comes easily departs easily. That which comes of struggle remains." ${ }^{\circ 0}$

This horizontal teaching-learning interchange also enhances the sense of community, as "hearts knit together" (Mosiah 18:21). The basic LDS teaching manual explains, "When we meet to learn the gospel, we do not come together merely as teachers, students, and friends. We come together as brothers and sisters-children of Heavenly Father. Our baptismal covenant further unites us.... [In Mosiah 18:21, we are urged to] 'look forward with one eye, having one faith and one baptism, having [our] hearts knit together in unity and in love one towards another." 81

Learning is enhanced for students who feel part of the interpretive community, who feel loved and understood in their struggles, and who understand how their peers apply gospel principles in similar situations. Since Church teachers are not trained theologians, exploring doctrine and its applications together becomes a means of making and cementing

79. For a detailed listing of the thought questions Jesus asked, see John W. Welch and John F. Hall, Charting the New Testament (Provo, Utah: Maxwell Institute, 2002), chart 9-16. For information on the questions answered by Jesus, see Welch and Hall, Charting the New Testament, chart 9-17.

8o. Elise Soukup, “The Mormon Odyssey," Newsweek, October 17, 2005, 55, 57 (quoting President Gordon B. Hinckley), available at http://www.news week.com/mormon-odyssey-121109. Soukup then observed, "Within limits, the church encourages internal debate, arguing that doubt can be an important precursor to faith."

81. "Teaching Others to Contribute to a Learning Atmosphere, Characteristics of a Learning Atmosphere," in Teaching, No Greater Call (Salt Lake City: Intellectual Reserve, 1999), 77. 
community. It is the immediacy and vitality of these local institutions that brings Mormons back to church every week. According to LDS historian Richard Bushman, "The sacred stories of [Mormonism] envelop Mormons in the realities of divine power and the redemption of Christ, without confining them to the specific formulation of a historic creed." ${ }^{82}$ The concept of "envelop" without "confining" astutely represents the sense of LDS religious understanding. The importance of these horizontal groupings in the Church may be part of what makes the faith a truly "American" religion. A Newsweek author suggested, "Smith's visionoptimistic, vigorous, a source of continuing personal growth for all who accept its blessings-in many ways echoes the American Dream." 83 Harold Bloom's assessment of the LDS religion notes the emphasis on "every individual's responsibility, perfectibility, and immediate accessibility to divine revelation coupled with its this-worldly communitarian imperatives." ${ }^{\prime 4}$ The sophistication and structure of a professionally developed theology would stunt this dynamic. This insight reflects not only on the synergy of this interactive learning, it also suggests the LDS focus on experience discussed in the next subsection.

Latter-day Saints have ownership over their religion not only through teaching and learning, but also from serving in other Church positions. All members are expected to contribute to the Church by holding a calling. In addition to the fact that most members regularly rotate in and out of positions as teachers, every member "owns" responsibility for learning and applying principles in evolving circumstances. The importance of this becomes clearer as we look at the next two spiritual principles.

\section{B. Personal Experience}

The sharing of leadership opportunities among lay members and the nature of the LDS classroom are forms that require active member engagement. An outside scholar, Mark Leone, claims that "Mormonism has meaning only in use." ${ }^{85}$ Such a statement could suggest that

82. Richard L. Bushman, Joseph Smith and the Beginnings of Mormonism (Urbana: University of Illinois Press, 1984), 188.

83. Soukup, "Mormon Odyssey," 60.

84. Eric A. Eliason, Mormons and Mormonism: An Introduction to an American World Religion (Urbana: University of Illinois Board of Trustees, 2001), 1, 14 (citing Harold Bloom, The American Religion: The Emergence of the PostChristian Nation [New York: Simon and Schuster, 1992], 117).

85. Leone, Roots of Modern Mormonism, 168. 
there is no LDS theology, only practical applications; however, this is not an accurate assumption. Latter-day Saints are encouraged to read, study, and seek inspiration in understanding God's eternal plan-every member a scriptorian. ${ }^{86}$ However, while knowledge at a theoretical level is desirable, ${ }^{87}$ ultimately it has little real value if not put to use. ${ }^{88}$ This sentiment is perhaps best understood in the context of James 2:14, 17: "What doth it profit, my brethren, though a man say he hath faith, and have not works? Can faith save him? . . . Even so, faith, if it hath not works, is dead, being alone." Frank Lloyd Wright put it this way: "The apprentice will be a true workman with proper pride in the doing, loving to see that doing well done. To be able to work at and for what one most wants to do well should be gospel in our democracy. For a democratic slogan try "What a man does that he has." 89

Leone continues, "At the heart of Mormonism is a continuous revision of meaning by the individual believer, a process facilitated by the immediacy and availability of revelation and the freedom to discuss all religious topics in the conviction that all can be equally well understood." 90 The horizontal structure of the Church and the absence of trained theologians focuses us less on "orthodoxy," from the Greek ortho + doxa (opinion), and more on "orthopraxy," from the Greek ortho + praxis (doing, action, or performance). ${ }^{91}$ Uniform doctrine is important and desirable, but that is not a central mission of the Church. Instead, the self-stated missions of the Church are all principles of action: perfect the saints,

86. See text accompanying notes 62-64 above.

87. See Doctrine and Covenants 90:15 ("Study and learn, and become acquainted with all good books, and with languages, tongues, and people"); Doctrine and Covenants 130:18-19 ("Whatever principle of intelligence we attain to in this life, it will rise with us in the resurrection. And if a person gains more knowledge and intelligence in this life through his diligence and obedience than another, he will have so much the advantage in the world to come").

88. See 2 Nephi 9:28-29: "O that cunning plan of the evil one! O the vainness, and the frailties, and the foolishness of men! When they are learned they think they are wise, and they hearken not unto the counsel of God, for they set it aside, supposing they know of themselves, wherefore, their wisdom is foolishness and it profiteth them not. And they shall perish. But to be learned is good if they hearken unto the counsels of God."

89. Wright, Genius and the Mobocracy, 85.

90. Leone, Roots of Modern Mormonism, 171.

91. See James A. H. Murray and others, Oxford English Dictionary, 1933 ed. (1970 reprint, Oxford University Press, 1933), 7:212, 215. 
proclaim the gospel, help the needy, and redeem the dead. ${ }^{92}$ The horizontal structure of the Church with the accompanying benefit of personal experience is vital to the fulfillment of these goals.

This orthopraxy gives life to a substantive LDS principle. The concept of "experience" is of special importance in LDS doctrine. The more valiant spirits in the premortal existence chose to come to earth to prove themselves and gain experience. ${ }^{93}$ Joseph Smith was counseled that adversity "shall give thee experience, and shall be for thy good" (D\&C 122:7). The need for personal experience is also taught by Paul in Romans: "We glory in tribulations also: knowing that tribulation worketh patience; and patience, experience; and experience, hope" (Rom. 5:3-4). ${ }^{94}$

Many careers are enhanced by on-the-job training, an apprenticeship, or some sort of clinical programs. Similarly, new Church members are given assignments immediately. Some quickly become bishops, Relief Society presidents, and other leaders; then they rotate out and have opportunity to serve in new capacities. Latter-day Saints read scriptures

92. "The Purpose of the Church", in Handbook 2: Administering the Church, 2.2, available at https://www.lds.org/handbook/handbook-2-administering-the -church/priesthood-principles ("The Church focuses on divinely appointed responsibilities. These include helping members live the gospel of Jesus Christ, gathering Israel through missionary work, caring for the poor and needy, and enabling the salvation of the dead by building temples and performing vicarious ordinances").

93. See, for example, The Church of Jesus Christ of Latter-day Saints, Guide to the Scriptures, s.v. "Premortal Life," http://www.lds.org/scriptures/gs/premortal-life ("All men and women lived with God as his spirit children before coming to the earth as mortal beings"); The Church of Jesus Christ of Latterday Saints, Guide to the Scriptures, s.v. "Council in Heaven," http://www.lds .org/scriptures/gs/council-in-heaven ("The occasion in premortal life when the Father presented his plan to his spirit children who would come to this earth"); Doctrine and Covenants 49:17 ("And that it might be filled with the measure of man, according to his creation before the world was made"); Doctrine and Covenants 138:53-56 ("Before they were born, [the leaders of the church and] others, received their first lessons . . . and were prepared to come forth"); Job 38:4-7 ("When [God] laid the foundations of the earth . . . the sons of God shouted for joy"); Abraham 3:22-25 (saying Abraham was chosen before he was born).

94. See also The Church of Jesus Christ of Latter-day Saints, Guide to the Scriptures, s.v. "Adversity," http://www.lds.org/scriptures/gs/adversity (“[Adversity creates] experiences that lead to spiritual growth and eternal progress"); Church of Jesus Christ of Latter-day Saints, Guide to the Scriptures, s.v. "Wisdom," http://www.lds.org/scriptures/gs/wisdom ("A person gains wisdom through experience and study and by following God's counsel”). 
and attend classes, but the form and function of the organization pushes them toward hands-on, experiential learning.

The importance of experience leads to what is perhaps an even more fundamental LDS principle. The goal in this mortal life for a member of the Church is a matter of experience or being, more than knowledge and intellect. The point is a change of heart-the changing of the "natural" or "carnal" person into a person who knows Jesus Christ (see Mosiah 3:19; Moro. 10:32, 33). Church historian Steve Olsen captured the subtle difference: "From a Mormon perspective, coming to know God is like getting to know a dear loved one, like a Heavenly Father. ... The process is not so much rational as relational." ${ }^{15}$ And being relational, it is personal, individual, and lived rather than cerebral. ${ }^{96}$

The change of heart that Latter-day Saints seek is not a one-time "born again" event but is an ongoing state of being. Alma asks, "If ye have experienced a change of heart, and if ye have felt to sing the song of redeeming love, I would ask, can ye feel so now?" (Alma 5:26). The result of this change of heart is to have no more desire to do evil (Alma 19:33). As this change of heart becomes ongoing, we are led to another principle: the goal of actually becoming like Jesus and as God is.

This sense of experience and change is a theme running through from the beginning of the LDS faith. Olsen concludes, "As in Mormon historiography, so in Mormon theology: the foundations are eventsspiritual experiences-that change the nature not just of a person's inner self, but also of the very essence of his world." ${ }^{\prime 7}$ Thus, the emphasis on orthopraxy is empowered by the horizontal structure of the Church and by its lack of trained theologians and scholarly interpretive methods, as discussed in the next subsection.

95. Steve Olsen, “Theology as a Cultural System," comments delivered at the University of Alabama, April 17, 2000, http://www.aliveonline.com/ldspapers/ StevesTalk.html.

96. The idea of relational theology is that "God ... allows itself to be known only to the extent that people are willing to engage it through personal relationship." Peter C. Hill and Todd W. Hall, "Relational Schemas in Processing One's Image of God and Self," Journal of Psychology and Christianity 21, no. 4 (2002): 365. Likewise, "the elementary impressions and emotional stirrings that waken the spirit of the 'natural man' proceed from incidents-experience of a being confronting him - and from situations - life with a being confronting him-that are relational in character." Martin Buber, I and Thou, trans. Walter Kaufmann (1923; London: Continuum International Publishing Group, 2004), 22.

97. Olsen, "Theology as a Cultural System." 


\section{Direct Light}

In addition to the emphasis on personal experience, the hierarchy of religious authority and canonical texts is balanced in the Church by the horizontal concept of individual revelation. The lay leadership and participant/learner forms in the Church translate into function: the canonical structure relies on continuing revelation and expects that individuals will receive personal revelation. ${ }^{98}$ Similarly, the lawmakers are part of a vertical structure with chains of authority, and yet each lawmaker is also expected to seek and obtain personal revelation to fill in the details of the application of doctrine in the exercise of such lawmaker's stewardships. Even the standard works and official prophetic declarations can only be rightly understood by the individual's active involvement in revelation.

The preeminence of direct light is illustrated by its relation to the canon of the LDS faith. Elder Dallin H. Oaks states, "For us, the scriptures are not the ultimate source of knowledge, but what precedes the ultimate source. The ultimate knowledge comes by revelation." 99 Members read scriptures to open their hearts and minds to communication from God. ${ }^{100}$ As Joseph Smith once stated, "I have ... the oldest book in my heart, even the gift of the Holy Ghost." ${ }^{101}$ A criticism of LDS doctrine is that it is circular-prophets will lead the Church in the right direction because a prophet said that is what will happen. ${ }^{102}$ This argument shows a lack of understanding as, in fact, members are encouraged to rely on personal revelation to receive a testimony of the authority and truthfulness of prophetic declarations. ${ }^{103}$ In this way, the horizontal elements of the Church strengthen and support the vertical structures, as the vertical structures could not stand alone.

98. See Church of Jesus Christ of Latter-day Saints, "Approaching Mormon Doctrine" ("This doctrine resides in the four 'standard works' of scripture, ... official declarations and proclamations, and the Articles of Faith.... Individual members are encouraged to independently strive to receive their own spiritual confirmation of the truthfulness of Church doctrine").

99. Oaks, "Scripture Reading and Revelation," 7. "Because we believe that scripture reading can help us receive revelation, we are encouraged to read the scriptures again and again. By this means, we obtain access to what our Heavenly Father would have us know and do in our personal lives today. That is one reason Latter-day Saints believe in daily scripture study" (italics in original).

100. Oaks, "Scripture Reading and Revelation," 8.

101. History of the Church, 6:308.

102. Ericson, "Challenges of Defining Mormon Doctrine," 71.

103. Oman, "Truth, Doctrine, and Authority," 15. 
Heber C. Kimball articulated the need for personal revelation: "The time will come when no man nor woman will be able to endure on borrowed light." ${ }^{104}$ The theme of knowing for oneself, without "borrowed light," has persisted as an important doctrine of the Church. ${ }^{105}$ It was expressed more recently by Elder James E. Faust: "We will not be able to travel through life on borrowed light. The light of life must be part of our very being. The voice we must learn to heed is the voice of the Spirit."106

Even though this concept of direct light is fundamental in its importance to the Church, the flexibility of continuing and individual revelation potentially could be a very dangerous and subversive horizontal concept in the sense that each person could become "a law unto himself." ${ }^{107}$ However, this danger is restrained by the vertical structure of unambiguous hierarchical authority in the Church and the concept of stewardshipgenuine revelations are only given about the recipient's stewardship-as well as the canon, the "measuring stick" against which to gauge impressions and visions to verify that individual revelation is harmonious with Church teachings. Thus, members must learn not only to seek and receive

104. Orson F. Whitney, Life of Heber C. Kimball, an Apostle, The Father and Founder of the British Mission (Salt Lake City: The Kimball Family, 1888), 461. Available online at https://archive.org/details/LifeOfHeberC.Kimball.

105. See, for example, J. Golden Kimball, "Conference Report," in SeventyFourth Annual Conference of The Church of Jesus Christ of Latter-day Saints (Salt Lake City: Deseret News Book Store, 1904), 28, available at http://scriptures.byu .edu/gc-historical/1904-A.pdf ("Latter-day Saints, you must think for yourselves. No man or woman can remain in this Church on borrowed light"); John Taylor and George Q. Cannon, "Defense of the Constitution of the U.S., May 26, 1885," in Clark, Messages of the First Presidency, 3:17 ("Those who have been careful to keep oil in their lamps, now have the needed light to guide them; and those who have been living in borrowed light, or in that furnished by others, may find themselves in perplexity and uncertain as to the path to pursue."); Harold B. Lee, "When Your Heart Tells You Things Your Mind Does Not Know," New Era 1 (Feb. 1971): 4, also available at https://www.lds.org/liahona/1978/o3/when-your-heart-tells-youthings-your-mind-does-not-know?lang=eng ("The time is here when each of you must stand on your own feet. Be converted, because no one can endure on borrowed light. You will have to be guided by the light within yourself").

106. James E. Faust, "The Voice of the Spirit," Ensign 24 (April 1994): 8, available at http://www.lds.org/ensign/1994/o4/the-voice-of-the-spirit.

107. Reynolds v. U.S., 98 U.S. 145, 167 (1878) (expressing disapproval at the idea that people could act contrary to U.S. law by excusing their actions with "religious belief"); see also Oman, "Truth, Doctrine, and Authority," 16-17 (saying that the concept of direct revelation is "radical spiritual egalitarianism" that is tempered by limits set by Church leaders). 
individual revelation, but to identify and weigh impressions to ascertain their veracity.

The concept of direct light is strengthened and reinforced in the Church by the absence of a vertical pillar of theologians. The fact that there is no formal theological training, no official trained interpreters, and no set methods of interpretation may function to give members of the Church greater flexibility in approaching the original texts. Members study in ways that suit them best, and receive individualized understanding of the scriptures that fits their particular circumstances. ${ }^{108}$ As members meet to share personal experiences, they can also share suggestions on how to best study the scriptures and seek revelation, a stark contrast to the rigidity of official interpretations from intellectuals handed down from acknowledged interpreters.

The absence of a theological pillar has a downside in that nonofficial LDS theologians can disseminate ideas that can become accepted or distorted by members of the Church, threatening the structure of stewardship. The concept of direct light balances this danger if members do not adopt credentialed people's ideas without first seeking direct light. Just as the horizontal concept of direct revelation can be a dangerous one, the opportunity to circulate misleading and even false doctrine in a Church that has limited official interpretations is staggering. Of course, there is a risk that a lack of official theologians may lead members to see themselves as LDS theologians charged to proclaim the "real" interpretation, not just for themselves and their stewardships but for everyone. In contrast to the informal applications discussed orally in local Sunday School classes, potentially misleading information or opinions published in widely circulated works by authors with impressive educational credentials, but not in the appointed chain of authority, have an even greater potential for harm. As discussed above, only the Apostles as a body have the authority to declare doctrine for the whole Church. ${ }^{109}$ LDS philosophers, like all other members, have authority

108. See The Church of Jesus Christ of Latter-day Saints, "Approaching Mormon Doctrine" ("The Church exhorts all people to approach the gospel not only intellectually but with the intellect and the spirit, a process in which reason and faith work together").

109. See Dennis B. Neuenschwander, "Living Prophets, Seers, and Revelators," Ensign 30 (November 2000): 41, available at http://www.lds.org/ ensign/2000/11/living-prophets-seers-and-revelators ("We sustain [fifteen] men [First Presidency and Twelve Apostles] not only as prophets and revelators but as seers also. The presence of seers among us is not much spoken of, 
to interpret gospel meaning only in their own individual stewardship. While the Church has a firm tradition of exploring ideas among and between members, including those who write scholarly works, ${ }^{110}$ challenges to the direct interpretations that have been issued through the lines of priesthood authority are unacceptable.

One concern is that statements or assumptions in publications by LDS intellectuals may eventually distill by word of mouth, through the media, or through the Internet, to groups whose gospel sophistication is not sufficient to properly process them. As Paul put it, "I have fed you with milk, and not with meat, for hitherto you were not able to bear it" (1 Cor. 3:2). In addition, statements in widely publicized works are often taken out of context. Finally, an idea which is neither endorsed by nor contrary to the Church authorities can become mistakenly accepted as Church doctrine and make its way into Sunday School classes and to members teaching from the podium. The risk that some may subtly claim authority or be taken as authorities exists even in the publication of articles such as this one, and I urge readers to take my statements as part of the horizontal teacher-learner discussion pattern. For these reasons, LDS scholars should exercise reasonable restraint when they publish their doctrinal "musings."

As a balance to the dangers of an unauthorized vertical propagation of theology, Church members are urged to seek direct light (a horizontal concept because it seeks confirmation outside the vertical human chain of authority) and that light should illuminate their own lives and their stewardship responsibilities. Light for the entire Church will come through the proper vertical channels. Thus, the forms join with the substance into one unified whole where the expectation is direct revelation, but the result is not anarchy.

In addition, the need of formal theology and theologians is lessened in the Church precisely because of the concept of direct light through priesthood stewardships. ${ }^{111}$ One quite apparent benefit of continuing revelation is that current prophets speak to new issues as they arise, and

yet the ability to see beyond the present lends power and authority to apostolic testimony and teaching").

110. See The Church of Jesus Christ of Latter-day Saints, "Approaching Mormon Doctrine" ("Journalists, academics and laymen alike are encouraged to pursue their inquiries into the Church by recognizing the broad and complex context within which its doctrines have been declared, in a spirit of reason and good will”).

111. See Wirthlin, "Let Every Man Learn His Duty," 69-71. 
their revelations may clarify and interpret words of ancient prophets from time to time. ${ }^{12}$ All LDS leaders from the prophet down to the lowliest are entitled to continuing revelation to answer questions and guide those within their stewardships, as discussed above. Thus, members of the Church have other routes to find the answers historically provided by theologians in other religions.

The authority hierarchy in the Church is made of individuals with no particular claim on education or expertise but who are generally chosen, by revelation, for their spiritual qualities or peculiar talents or to forward some other purpose known to God. As discussed above, inserting at any point an erudite elite would fundamentally change the form of the Church and the substance of the doctrine. ${ }^{113}$ Latter-day Saints take

112. See Oaks, "Scripture Reading and Revelation," 7.

113. The fact that we believe in continuing revelations given through anointed authorities (both as lawgivers and interpreters) and given directly to individuals does not mean that other meaningful study and commentary is not useful. Members of the LDS Church are strongly urged to pursue "book learning" and education of all kinds, and volumes of scholarly work by members about the Church, the scriptures, and doctrine have been, and are being, written. See Doctrine and Covenants 109:7; 88:117-41; 90:15; Article of Faith 13. Nonetheless, such research is not seen as essential to understanding God's will for us. See Gordon B. Hinckley, "Four Cornerstones of Faith," Ensign 34 (February 2004): 6, available at http://www.lds.org/ensign/2004/o2/four-cornerstones-of-faith. In fact, we are strongly warned that "to be learned is good [only if we] hearken unto the counsels of God" (2 Ne. 9:29). LDS writers have devoted many pages to reservations about "intellectuals" based on this scripture. See, for example, Robert L. Millet, To Be Learned Is Good, If. . (Salt Lake City: Bookcraft, 1987); Boyd K. Packer, "To Be Learned Is Good If ...," Ensign 22 (November 1992): 71, available at https://www.lds.org/general-conference/1992/10/to-be-learned -is-good-if?lang=eng. Harold B. Lee, “The Iron Rod," Ensign 1 (June 1971): 5, 8, available at http://www.lds.org/ensign/1971/06/the-iron-rod (containing Harold B. Lee's assertion that "I heard one ... say ... that he believed more professors have taken themselves out of the Church by their trying to philosophize or intellectualize the fall of Adam and the subsequent atonement of the Savior. This was because they would rather accept the philosophies of men than what the Lord has revealed"); Joseph F. Smith, Gospel Doctrine: Selections from the Sermons and Writings of Joseph F. Smith, Sixth President of The Church of Jesus Christ of Latter-day Saints (Salt Lake City: Deseret Book, 1939), 373 (containing Joseph F. Smith's suggestion that secular scholars "read by the lamp of their own conceit"); Dallin H. Oaks, The Lord's Way (Salt Lake City: Deseret Book, 1991), 64-67 (expounding the sequential relationship between reason and revelation-first one reasons and ponders and studies for the correct answer and then supplements or replaces that with spiritual knowledge). 
an active ownership in religious knowledge and practice and rely on intimate, personal insight.

Joseph Smith, the first prophet of the Restoration, resisted creeds because they stifled discovery of further truth. ${ }^{114}$ Louis Midgley in the Encyclopedia of Mormonism explains: "The core of [LDS] faith is not a confession to a creed but a personal witness that Jesus of Nazareth is the Christ." ${ }^{\prime 15}$ President Gordon B. Hinckley offered a telling insight on the relationship of commentary, scriptures, and revelation in the LDS tradition: "I do not concern myself much with reading long commentary volumes designed to enlarge at length upon that which is found in the scriptures. Rather, I prefer to dwell with the source, tasting of the unadulterated waters of the fountain of truth." 116

114. Terryl L. Givens, “Joseph Smith: Prophecy, Process, and Plentitude," in Joseph Smith Junior: Reappraisals after Two Centuries, ed. Reid L. Neilson (Oxford: Oxford University Press, 2008), 110 (“This resistance to formal creeds, to a closed canon, and to conventional opinion are all so many versions of resistance to finality, to fixity or what he called 'circumscription'-being bound and hemmed in by orthodoxy"); see also JS-H 1:19 (containing Joseph Smith's vision of Jesus Christ and Christ's declaration that the "creeds [of the then extant churches] were an abomination in his sight"); Joseph Fielding McConkie, Here We Stand (Salt Lake City: Deseret Book, 1995) 160-78 (equating creeds with apostasy); LeGrand Richards, "Strange Creeds of Christendom," Ensign 3 (January 1973): 109, available at http://www.lds.org/ensign/1973/o1/ strange-creeds-of-christendom (criticizing a number of creeds as generally human inventions); John W. Welch, “All Their Creeds Were an Abomination': A Brief Look at Creeds as Part of the Apostasy," in Prelude to the Restoration: From Apostasy to the Restored Church, ed. Steven C. Harper, and others (Salt Lake City: Deseret Book, 2004), 228, 231 ("Latter-day Saints should not take issue so much with any single creed as with the whole concatenation of creedal formulations in general"). See generally Michael Hicks, "Do You Preach the Orthodox Religion? Thoughts on the Idea of Heresy in the Church," Sunstone 6, no. 5 (September-October 1981): 31, which argues that the development of creeds reduced early Christianity to strict vertical authority (quoting Edward J. Machle, "How Is a Heresy False?" in Studies in Religion/Sciences Religieuses 1 [1971]: 228). While the Articles of Faith seem to resemble a creed, they tend to be more action-focused and to a large extent reflect the life experiences of their author, Joseph Smith. John W. Welch, "The Articles of Faith and the Life of Joseph Smith," Ensign 43 (December 2013): 70, available at http://www.lds.org/ ensign/2013/12/the-articles-of-faith-and-the-life-of-joseph-smith.

115. Louis C. Midgley, “Theology," in Ludlow, Encyclopedia of Mormonism, 4:1475.

116. In LDS doctrine, as discussed above, the ultimate source of truth is God and scriptures are secondary. The quote by President Hinckley may be 
Thus, the horizontal organization of the Church-including gospel ownership, personal experience, and direct light-is critical to the continuity of the Church and is balanced by the more formal vertical structures. Both the horizontal and vertical structures of the Church exist to facilitate the Church's function: to effect God's plan of bringing about the salvation and exaltation of his children.

\section{Cardston Alberta Temple as Example}

One modern-day temple reflects the theory Frank Lloyd Wright proposed and also stands as an example of the unity achieved between the form and function of the Church. The Cardston Alberta Temple was built in 1912 and was designed by Hyrum Pope and Harold Burton. ${ }^{117}$ The designers of the temple followed Frank Lloyd Wright's style but also incorporated what may have seemed disjointed to some: remembrances of the "preColumbian ruins of Mexico and Latin America." ${ }^{118}$ The bold design of the temple rose naturally from its surroundings to encompass the eternal function for which it was built. Paul L. Anderson beautifully described the brilliance of its integrated design:

As [the designers] envisioned them, the four ordinance rooms would be arranged around the center of the building like

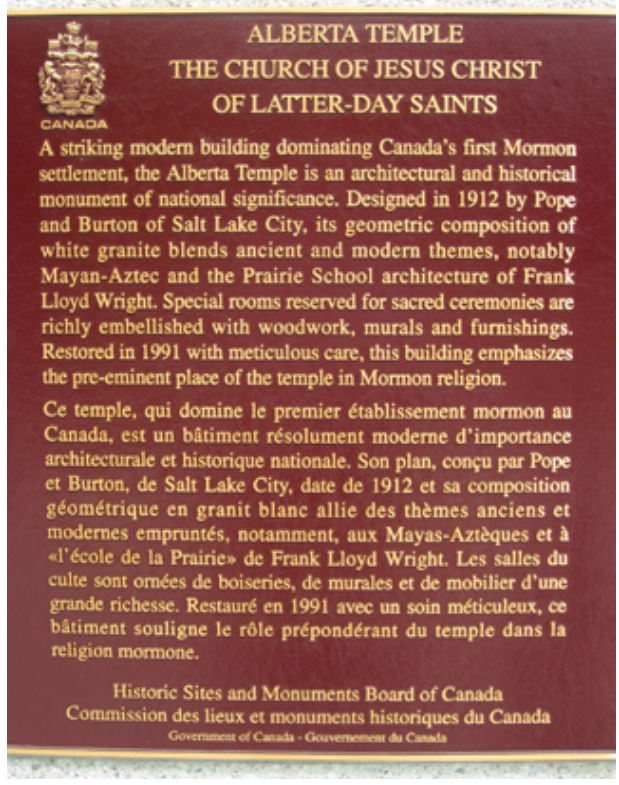

Plaque at the Cardston Alberta Temple pointing to the influence of architect Frank Lloyd Wright.

read to include going to the original texts of the scriptures and going to the Lord in prayer. Gordon B. Hinckley, "Feasting upon the Scriptures," Ensign 15 (December 1985): 45, available at http://www.lds.org/ensign/1985/12/feasting -upon-the-scriptures.

117. Paul L. Anderson, “First of the Modern Temples," Ensign 27(July 1977): 8-9, available at http://www.lds.org/ensign/1977/o7/first-of-the-modern-temples.

118. Anderson, "First of the Modern Temples," 10. 


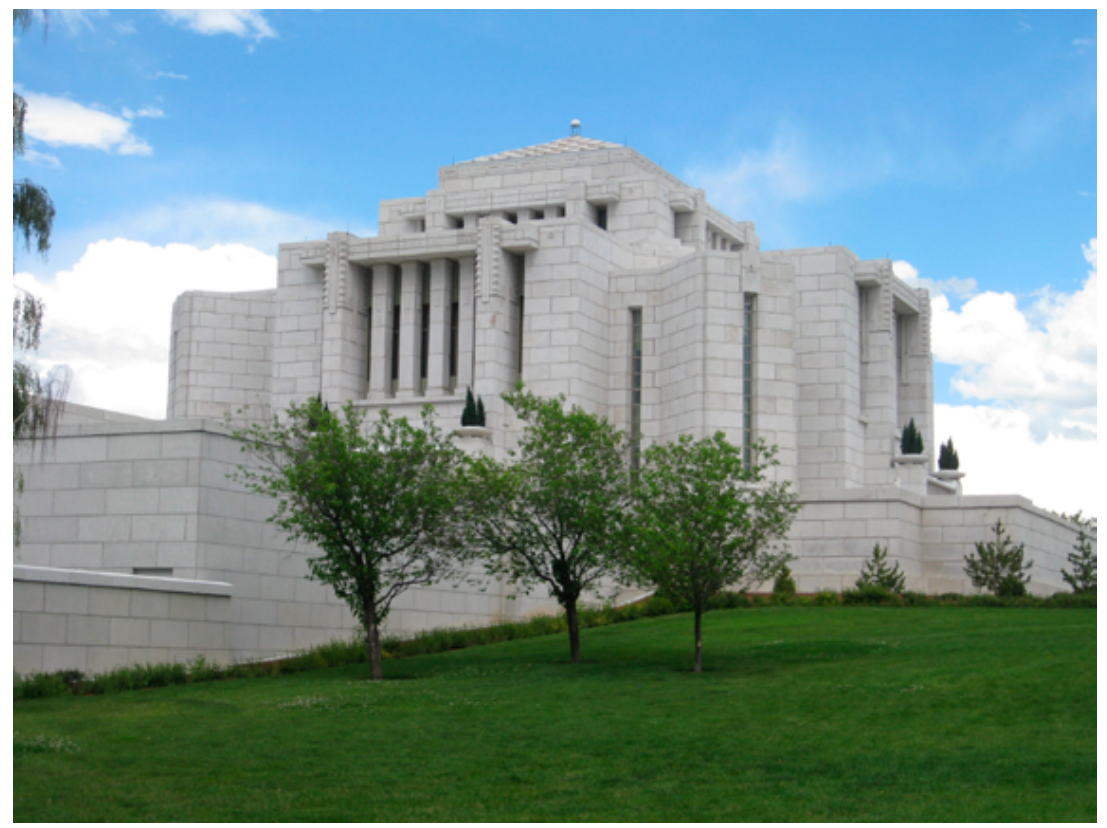

Cardston Alberta Temple, which combines the influences of Frank Lloyd Wright and Mayan-Aztec architecture.

the spokes of a wheel, each room facing one of the cardinal directions. The celestial room would be placed in the center at the very top of the building, with the baptistry directly below. This arrangement placed the rooms in a practical and symbolically appropriate relationship to each other. As a person moved through the ordinance rooms he followed a circular path, finally coming through into the center in the celestial room. Each room was also a few steps higher than the one before, with the celestial room and the adjacent sealing rooms being the highest of all. Thus, the architectural arrangement expressed the same idea of progression that is found in the temple ceremony itself.

The design of the outside of the building was equally satisfying. The unity of interior and exterior, a basic principle of modern architecture, was evident in the fact that the major rooms inside were the most prominent features outside as well. ${ }^{119}$

The interior furnishings and ornamentations of the Cardston Alberta Temple were all similarly designed to incorporate natural local elements

119. Anderson, "First of the Modern Temples," 10. 
and woods. The temple's beautiful form naturally serves its function while, at the same time, the function gives meaning and value to each element of the form. ${ }^{120}$ Such was the fulfillment of Frank Lloyd Wright's intent that form and function be one, as well as the LDS concept that heaven and earth can be joined in a temple.

\section{Conclusion}

Outsiders trained in traditional theological method may agree with Bernard DeVoto's 1936 critical assessment that a "complete bibliography of [theological] articles by qualified [LDS] scholars would not fill [a single] page." ${ }^{21}$ But perhaps they drive by too fast. Perhaps they do not notice a building unadorned, plain as a tree. A closer examination may reveal a structure that gives both vitality and meaning to LDS thought.

The Church has at its core a spiritual union of form and function, which gives independent life to the organization. The materials (people and organizations) that constitute its internal form are woven together into a living fabric by the functions those materials serve. In his architecture, Frank Lloyd Wright sought "a spiritual union" of form and function to overcome the limitations of time. "Frank Lloyd Wright's organic architecture ... involves a respect for the properties of the materials ... and a respect for the harmonious relationship between the form/ design and the function of the building. ... Organic architecture is also an attempt to integrate the spaces into a coherent whole: a marriage between the site and the structure and a union between [structure] and ... context." 122

This critical connection of form and function is evident in the LDS Church. The Church has its lawgivers and its canon-its vertical structures; it also has its horizontal structures-just as a building has both

120. See generally, Anderson, "First of the Modern Temples," 6-11 (discussing the detailed work of the interior and exterior design and the way each element lends itself to the function of the temple).

121. Bernard DeVoto, Forays and Rebuttals (New York: Little Brown and Company, 1936), 82-83.

122. Kimberly Elman, "Frank Lloyd Wright and the Principles of Organic Architecture," PBS.org, http://www.pbs.org/flw/legacy/essay1.html. This union of form and function is not unique to the LDS Church. Robert Summers, a leading scholar, has stated that the concepts of equality and democracy are realized through "the duly constructed units of electoral, legislative, and related institutions and processes." Robert S. Summers, Form and Function in a Legal System-a General Study (Cambridge: Cambridge University Press, 2006), 21. 
walls and floors. Like the Frank Lloyd Wright ideal, the Church's function, joined to its form, creates the opportunities for the development of spiritual substance, a spiritual edifice in which members are owners who learn through personal experience and receive direct light from God as they strive toward salvation and exaltation.

Note how Paul in his epistle to the Ephesians describes how both the horizontal and vertical elements discussed above unite with the spiritual function they serve: "Now therefore ye are no more strangers and foreigners, but fellowcitizens with the saints, and of the household of God [horizontal structure]; and are built upon the foundation of the apostles and prophets, Jesus Christ himself being the chief corner stone [vertical structure]; in whom all the building fitly framed together groweth unto an holy temple in the Lord: in whom ye also are builded together for an habitation of God through the Spirit [substantive function]" (Eph. 2:19-22). Latter-day Saints would do well to "seek for a greater understanding as to why we are thus organized and then to seek to fulfill the vision [God] has for us." 123

Cheryl B. Preston is Edwin M. Thomas Professor of Law in the J. Reuben Clark Law School at Brigham Young University. She would like to express her gratitude for the editing assistance of Alison Craig and Brandon Gardner; the helpful comments on earlier drafts given by Frederick Mark Gedicks, John W. Welch, David H. Bailey, Brett Scharffs, Galen Fletcher, Ross Boundy, and the participants in the J. Reuben Clark Society conference in Washington, D.C.; and the research assistance of Bradley Schmidt, Debra Linford, Jill Rencher, Javier Farfan, Nate Whittaker, and the entire reference staff at the Howard W. Hunter Law Library. She adds, "I dedicate this article to LaMont Erickson, a good friend who helped me formulate the concepts of structure and form and who recently thereafter moved on to a better place."

123. Julie B. Beck, "Why We Are Organized into Quorums and Relief Societies," BYU Devotional, January 17, 2012, Provo, Utah, transcript available at http://speeches.byu.edu/reader/reader.php?id=13577\&x=49\&y=5. 